\title{
NEW GOVERNMENT CENTER OF GROBOGAN DISTRICT IN PURWODADI DISTRICT WITH NEO VERNACULAR PUSAT PEMERINTAHAN BARU KABUPATEN GROBOGAN DI KECAMATAN PURWODADI DENGAN PENDEKATAN ARSITEKTUR NEO VERNAKULAR
}

\author{
Hidayatul Mustafit ${ }^{1)}$, Mutiawati Mandaka ${ }^{2)}$, Adi Sasmito ${ }^{3)}$ \\ Program Studi Arsitektur, Fakultas Teknik, Universitas Pandanaran \\ mustafit@unpand.ac.id \\ mutia.mandaka@unpand.ac.id \\ adisas@unpand.ac.id
}

\begin{abstract}
Abstrak
Pemerintah Kabupaten merupakan unsur utama dalam penyelenggaraan pemerintah di daerah yang berupa sub sistem dalam sistem pemerintahan Negara. Dalam hal perencanaan dan perancangan pusat pemerintahan baru kabupaten grobogan di kecamatan purwodadi mempunyai tujuan agar terpenuhinya kebutuhan ruang yang kurang memadai dalam pelayanan masyarakat serta memudahkan komunikasi antar sub sistem dalam pemerintah daerah agar tercapai sebuah tujuan bersama. Issue tersebut, tertanggapi oleh pemerintah daerah khususnya merupakan program yang harus di persiapkan untuk pemerintahan masa mendatang. Kecamatan Purwodadi Merupakan pusat kota dari kabupaten grobogan yang mempunyai potensi sebagai pusat pemerintahan dan telah mempunyai alun-alun sebagai tempat berkumpulnya masyarakat. Potensi sekaligus menjawab issue untuk penetapan letak pusat pemerintah kabupaten grobogan. Konsep Arsitektur yang di gunakan dalam perencanaan dan perancangan pusat pemerintahan ini menggunakan pendekatan Arsitektur Neo Vernakular dengan memperhatikan aspek kebudayaan, kondisi geografis dan rumah adat istiadat daerah setempat. Melalui Perencanaan dan Perancangan Pusat Pemerintahan Baru Kabupaten Grobogan Di Kecamatan Purwodadi menjadi sebuah kawasan dari pusat pemerintahan daerah yang baik dan memadai agar mendukung kinerja dan kualitas pemerintahan, serta memberikan pelayanan yang terbaik untuk masyarakat, memberikan publik space yang memadai untuk mendekatkan masyarakat dengan pemerintah karena pemerintah yang baik adalah pemerintah yang dekat dengan rakyatnya.
\end{abstract}

\section{Kata Kunci : Pusat Pemerintahan Kabupaten, Arsitektur Neo Vernakular, Rumah Joglo} Abstract

District government is the main element in the administration of local government in the form of subsystems in the state government system. In terms of planning and designing the new central government of Grobogan district in Purwodadi sub-district, the goal is to fulfill the need for inadequate space in public services and facilitate communication between sub-systems in local government in order to achieve a common goal. The issue, which was responded to by the local government in particular, is a program that must be prepared for future government. Purwodadi District is the city center of Grobogan district which has the potential as a center of government and already has a square as a community gathering place. Potential as well as answering the issue of determining the location of the central government of the Grobogan district. The architectural concept used in the planning and design of this central government uses the Neo Vernacular Architecture approach by taking into account aspects of culture, geographical conditions and local traditional houses. Through the Planning and Design of the New Government Center, Grobogan Regency in Purwodadi District became an area of a good and adequate regional government center in order to support the performance and quality of government, and provide the best service for the community, providing adequate public space to bring the community closer to the government because the government What is good is a government that is close to its people.

Keywords: District Government Center, Neo Vernacular Architecture, Joglo House 


\section{PENDAHULUAN}

Pusat Pemerintahan kabupaten/kota merupakan organisasi dari system atau unsur pemerintah dalam lingkup daerah atau kota yang mengatur otonomi daerah. Dalam perancangan pusat pemerintahan baru ini menganut berdasarkan PP No 18 Tahun02016 tentang perangkat daerah dan di perbarui di PP No. 72 tahun 2019, pusat pemerintahan terdiri atas:
a. Sekretariat Daerah :
-Bupati
-Wakil Bupati
- Sekertaris Daerah
-Asisten Daerah
b. Sekretariat DPRD;
c. Inspektorat;
d. Dinas;
e. Badan; dan
f. Kecamatan

Menurut W.S Sayre (1960) dalam definisi terbaiknya pemerintah adalah suatu bentuk organisasi sebuah negara yang berkedaulat terhadap kekuasaan yang di dudukinya. (sumber: Inu Kencana Syafiie, Pengantar ilmu pemerintahan, Jakarta, Refika Aditama.)

Selanjutnya menurut David Apter (1977), pemerintah adalah satuan anggota yang umum dan memiliki wewenang tertentu untuk memperkuat system yang meliputi dan monopoli praktis yang berhubungan dengan kekuasaannya. (sumber: Inu Kencana Syafiie, Pengantar ilmu pemerintahan, Jakarta, Refika Aditama.)

Pemerintahan adalah pelaksana tugas pemerintah atau Bescturvoering, dalam pengertian Pemerintah adalah organisasi yang memonitor pemerintahan. (sumber: Ridwan HR, Hukum Administrasi Negara, UII Press, Yograkarta, 2002).

\section{Preseden}

\section{Kantor Pemerintahan Kabupaten Bandung}

Kantor Pemerintah Kabupaten Bandung berlokasi di Jl. Perkantoran Pemerintah Kab.
Bandung, Pamekaran, Kec. Soreang, Bandung, Jawa Barat. Penataan gedung yang rapi sangat dibutuhkan agar seluruh jajaran pemerintah dapat berkoordinasi dengan baik satu sama lain, agar tidak terjadi mis komunikasi terhadap keputusan-keputusan yang telah dibuat dan di sepakati. Gedung yang berdekatan ini memudahkan Bupati untuk mengkontrol kinerja para bawahan yang ada di wilayah pusat Pemerintahan Kabupaten Bandung.

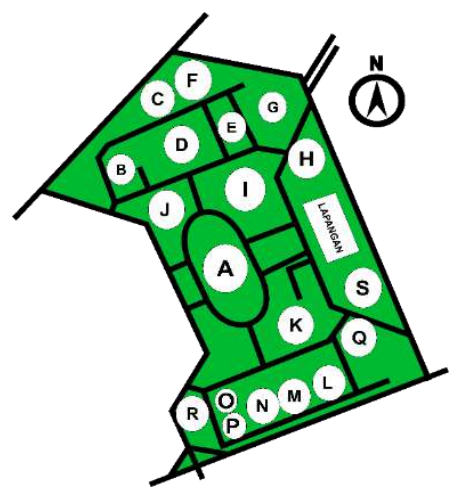

Gambar 1. Penataan Kantor Pemerintah Kabupaten Bandung

Keterangan :

A. Kantor Bupati

B. Dinas Kesehatan

C. Dinas Peternakan \& Perikanan

D. Dinas Perindustrian dan perdagangan

E. Dinas Perumahan, Tata Ruang dan Kebersihan

F. BPBD

G. Badan Pertahanan Nasional

H. Masjid

I. Dinas Pendidikan dan Kebudayaan

J. Dinas Sosial

K. Badan Perencanaan Pembangunan Daerah

L. Dinas Ketenagakerjaan

M. Inspektorat

N. Dinas Sumber Daya Air, Pertambangan dan Energi

O. Dinas Lingkungan Hidup

P. Dinas Pemberdayaan Masyarakat dan desa

Q. Bank BJB

R. Dinas Kependudukan dan Catatan Sipil

S. Dinas Penanaman Modal dan Pelayanan Terpadu Satu Pintu.

\section{Kantor Pemerintah Kabupaten Bekasi}

Kantor Pemerintah Kabupaten Bekasi berlokasi di Sukamahi, Kecamatan Cikarang pusat, Bekasi, Jawa. Sebagai salah satu pusat pemerintahan di Jawa Barat, kantor pemerintah 
Kabupaten Bekasi ini mempunyai ciri tersendiri yang terpusatkan oleh lapangan terbuka hijau.

Pusat Pemerintahan yang berbentuk Pentagonal dengan luas $\pm 40 \mathrm{Ha}$ yang terbangun berbagai badan pemerintahan di dalamnya.

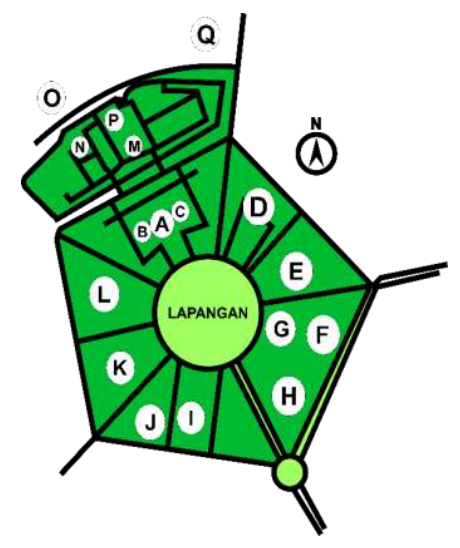

Gambar 2 Site plan Pusat Pemerintah Kabupaten Bekasi

Keterangan :

A. Gedung Kantor Bupati, Badan

Pengelolaan Keungan Daerah

B. Gedung Inspektorat

C. Gedung Bappeda

D. Gedung Serba Guna dan Pengadilan Negeri

E. Gedung Dinas Pariwisata, budaya, Pemuda dan Olahraga, Dinas Pedapatan daerah, Dinas Kependudukan dan catatan sipil

F. Kodim Bekasi 0509

G. Kejaksaan Negeri

H. Kantor Polisi

I. Kantor DPRD

J. Badan Pusat Statistik

K. Dinas Kementrian Lingkungan Hidup, Dinas PUPR, Dinas Pertanian, Dinas Ketenagakerjaan, Dinas Kesehatan, Dinas Perindustrian dan Perdagangan.

L. Masjid, Pengadilan Negeri, Kementrian Agama.

M. Rumah Dinas

N. Lapangan Basket

O. Badan Penanggulangan Bencana Daerah

P. Diskominfo

Q. Gedung ULP

\section{TINJAUAN TEORI}

Pendapat Tjok Pradnya Putra dalam Pengertian Arsitektur Neo-Vernacular, memberikan penjelasan bahwa Neo berarti dalam Bahasa Yunani yang di pergunakan sebagai fonim yang artinya baru. maka Neo-
Vernacular dapat diartikan dengan bahasa setempat yang dipaparkan dengan cara baru, arsitektur Neo-Vernacular adalah sebuah penerapan dari unsur arsitektur yang sebelumnya ada, baik segi bentuk, konstruksi maupun konsep, filosofi dan tata ruang dengan mengedepankan pelestarian dari unsur local yang terbentuk secara empiris dari sebuah kebudayaan tradisi yang mengalami sedikit atau banyaknya perubahan menuju sebuah karya yang terbaru dan modern tanpa meningggalkan sebuah nilai tradisi yang telah ada di tempat tersebut.

Berikut Ciri khas gaya Arsitektur0Neo Vernakular, dari pernyataan Charles Jencks dalam bukunya "language of Post-Modern Architecture"maka dapat dipaparkan ciri-ciri Arsitektur Neo-Vernacular berikut ini :

a. Bangunan identik dengan atap bubungan

b. Atap bubungan cenderung menutupi tembok hingga sampai ketanah dan banyak yang bangunan yang atapnya menggantikan sebagai elemen pelindung di bandingkan dengan tembok yang melampangkan perlindungan.

c. Penggunaan material Batu bata (yang disebut elemen konstruksi dari lokal)

d. Bangunan kebanyakan menggunakan batu bata abad 19 gaya Victorian yang menjadi budaya lokal dari arsitektur barat.

e. Bangunan cenderung ramah terhadap lingkungan dan melestarikan bentuk tradisional dengan proporsi lebih modern.

f. Menyatukan interior dengan ekterior ruang dengan melalui elemen modern.

g. Memiliki waarna yang dominan dan kontras.

\section{METODOLOGI PERANCANGAN}

Metode mencakup pendekatanpendekatan yang digunakan, seperti :

\section{- Pendekatan Aspek Kontekstual}

Pemilihan tapak untuk Perancangan Pusat Pemerintahan Baru di Kabupaten Grobogan berlokasi di pusat kota tepatnya di Jln. Gatot subroto, Kec. Purwodadi, Kab. Grobogan, dengan luas lahan $149.600 \mathrm{~m} 2$ / 14,96 ha, dengan arah orientasi menghadap ke Alun-alun, dan batasan tapak sebagai berikut : 
- Utara :Permukiman, Sekolah Dasar

- Selatan :Permukiman, Toko.

- Timur :Permukiman,

Gedung

Pendidikan.

- Barat :Permukiman, Ruko-ruko.

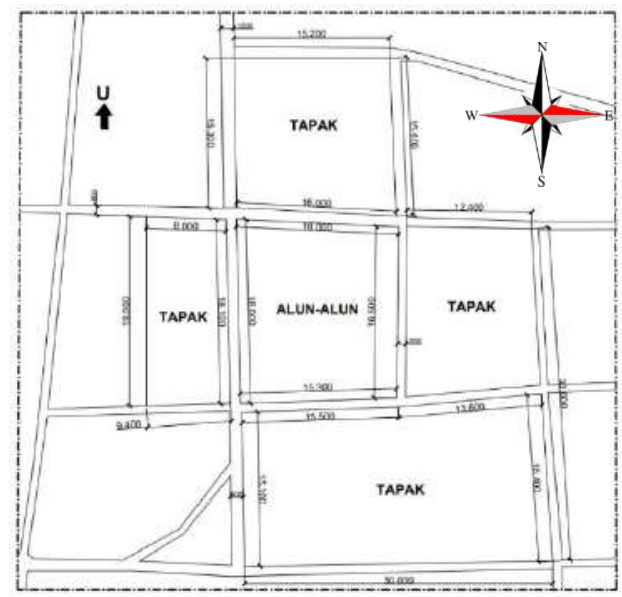

Gambar 3 Lokasi Tapak

- Pendekatan aspek fungsional

- Besaran Ruang dan kebutuhan ruang

Tabel 1 Program ruang Pusat Pemerintahan Kabupaten Grobogan

\begin{tabular}{|c|c|c|}
\hline \multicolumn{3}{|c|}{ LUAS KEBUTUHAN RUANG } \\
\hline No & Program Kebutuhan Ruang & Luas Ruang \\
\hline 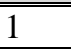 & Gedung Skretariat Daerah & $4.785,235 \mathrm{~m} 2$ \\
\hline 2 & Rumah Dinas Bupati & $638,82 \mathrm{~m} 2$ \\
\hline 3 & Gedung Skretariat DPRD & $1.456,78 \mathrm{~m} 2$ \\
\hline 4 & Gedung BAPPEDA & $1.708,59 \mathrm{~m} 2$ \\
\hline 5 & Gedung Inspektorat & $1.108,64 \mathrm{~m} 2$ \\
\hline 6 & Gedung Dinas Pendidikan & $1.647,75 \mathrm{~m} 2$ \\
\hline 7 & Gedung Dinas kesehatan & $1.647,75 \mathrm{~m} 2$ \\
\hline 8 & $\begin{array}{l}\text { Gedung Dinas Pekerjaan } \\
\text { Umum Dan Penataan Ruang }\end{array}$ & $2.127,71 \mathrm{~m} 2$ \\
\hline 9 & $\begin{array}{l}\text { Gedung Dinas Perumahan } \\
\text { Rakyat Dan Kawasan } \\
\text { Permukiman }\end{array}$ & $1.335,1 \mathrm{~m} 2$ \\
\hline 10 & Gedung Dinas Sosial & $1.335,1 \mathrm{~m} 2$ \\
\hline 11 & Masjid/tempat ibadah & $1.629,16 \mathrm{~m} 2$ \\
\hline 12 & Fasilitas Pelengkap & $32.510 \mathrm{~m} 2$ \\
\hline & Total Keseluruhan & $51.930,635 \mathrm{~m} 2$ \\
\hline
\end{tabular}

\section{- Program Hubungan Ruang Makro}

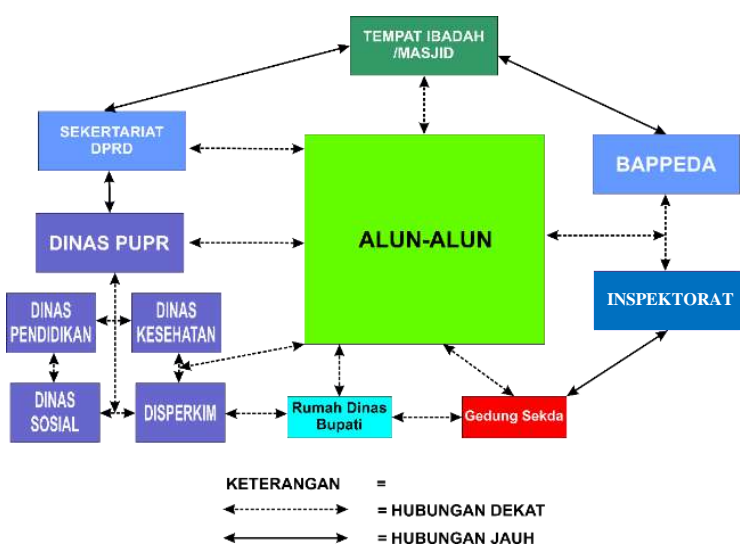

Gambar 4 Program Hubungan Ruang Makro

\section{- Pendekatann Pelaku Kegiatan, pendekatan aktivitas dan kebutuhan} ruang

a. Gedung Sekretariat Daerah

Menampung pelaku kegiatan antara lain :

- Bupati

- Wakil Bupati

- Sekretariat daerah

- Asisten Daerah

- Kepala Sub Bidang

- Pegawai/staff Masing-masing ka subag

b. Gedung Sekretariat DPRD

Menampung pelaku kegiatan antara lain :

- Ketua DPRD

- Sekretariat DPRD

- Kepala Sub Bidang

- Kelompok Jabatan Fungsional Tertentu / Saff

c. BAPPEDA (Badan Perencanaan Pembangunan Daerah)

Menampung pelaku kegiatan antara lain :

- Ketua Badan

- Sekretaris

- Kepala Bidang

- Kepala Sub Bidang

- Kelompok Jabatan Fungsional Tertentu / Saff

d. Inspektorat

Menampung pelaku kegiatan antara lain :

- Instruktur 
- Sekretaris Inspektorat

- Kepala Sub Bagian

- Inspektur Pembantu wilayah $1,2,3$

- Kelompok jabatan fungsional tertentu / staff

e. Dinas Pendidikan

Menampung pelaku kegiatan antara lain :

- Kepala Dinas

- Sekretaris

- Ka Subbag

- Kepala Bidang SD,SMP,SMA

- Kasi Bidang SD,SMP,SMA

- Kelompok Jabatan Fungsional Tertentu / Saff

f. Dinas Kesehatan

Menampung pelaku kegiatan antara lain :

- Kepala Dinas

- Sekretaris

- Ka Subbag

- Kepala Bidang

- Kasi Bidang

- Kelompok Jabatan Fungsional Tertentu / Saff

g. Dinas PUPR

Menampung pelaku kegiatan antara lain :

- Kepala Dinas

- Sekretaris

- Ka Subbag

- Kepala Bidang

- Kasi Bidang

- Kelompok Jabatan Fungsional Tertentu / Saff

h. Dinas Perumahan Rakyat dan Kawasan Permukiman

Menampung pelaku kegiatan antara lain :

- Kepala Dinas

- Sekretaris

- Ka Subbag

- Kepala Bidang

- Kasi Bidang

- Kelompok Jabatan Fungsional Tertentu / Saff i. Dinas Sosial

Menampung pelaku kegiatan antara lain :

- Kepala Dinas

- Sekretaris

- Ka Subbag

- Kepala Bidang

- Kasi Bidang

- Kelompok Jabatan Fungsional Tertentu / Saff

Aktivitas Dari Masing-masing pelaku kegiatan antara lain:

- Parkir kendaraan

- Absensi

- Mengkoordinasikan staf

- Menerima tamu

- Menandatangani Analisa

- Rapat/diskusi

- Isoma

\section{PEMBAHASAN}

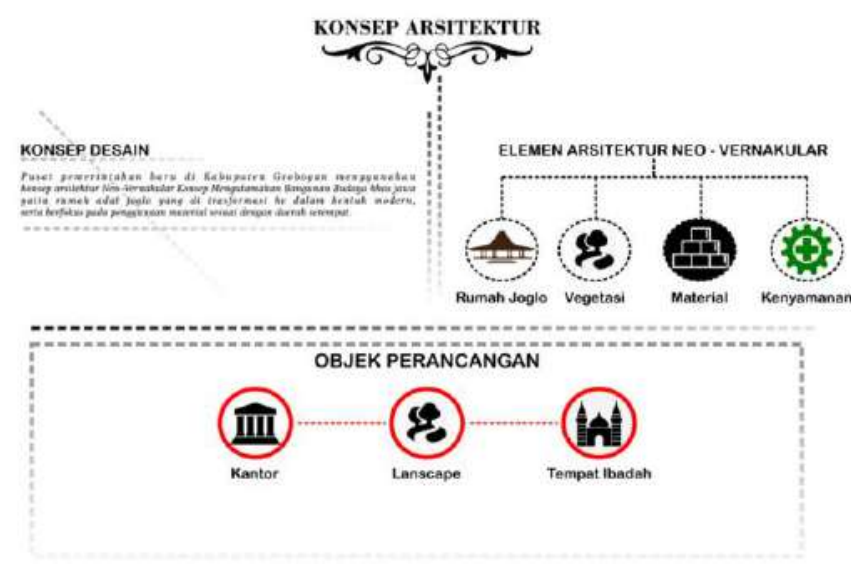

Gambar 5 Konsep Arsitektur

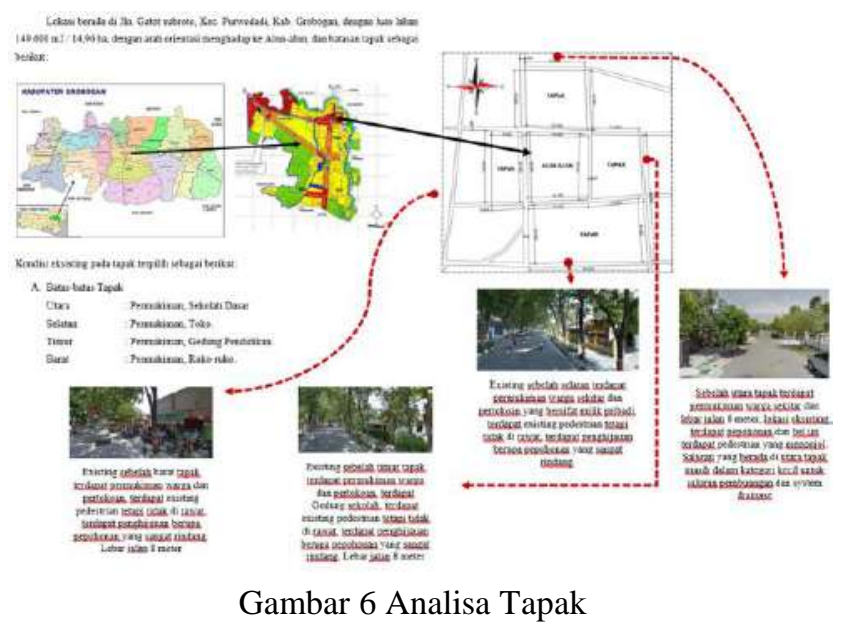




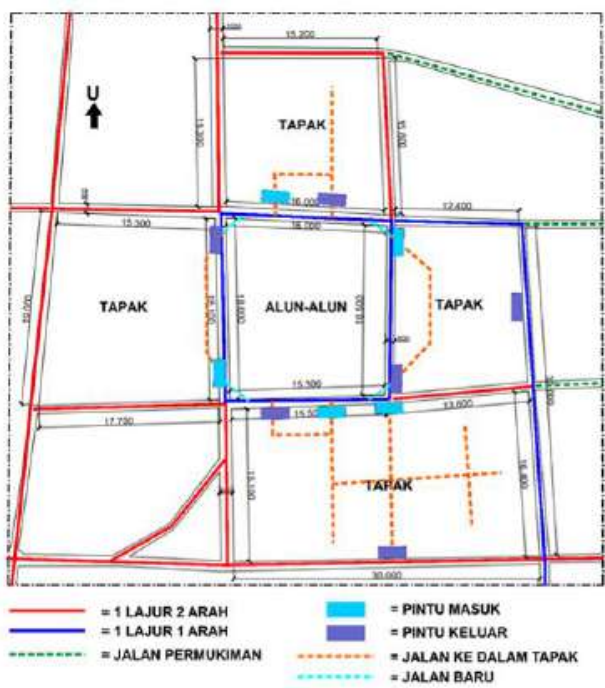

Gambar 6 Analisa Aksesibilitas

Keterangan :

Tapak yang di akses dari berbagai arah namun memisahkan antara pejalan kaki dan akses kendaraan.

- Akses masuk dan keluar di buat menjadi beberapa tempat sesuai dengan zoning yang di terapkan di tapak.

- Membuat petunjuk arah bertujuan untuk memperjelas masuk kendaraan pada setiap zoning

- Menata Kembali pedestrian untuk pejalan kaki dan membuat public space yang memadai.

- Dengan adanya pemisahan sirkulasi masuk dan keluar di setiap zoning membuat pengunjung atau masyarakat yang berkunjung dapat mengaksesnya secara cepat.

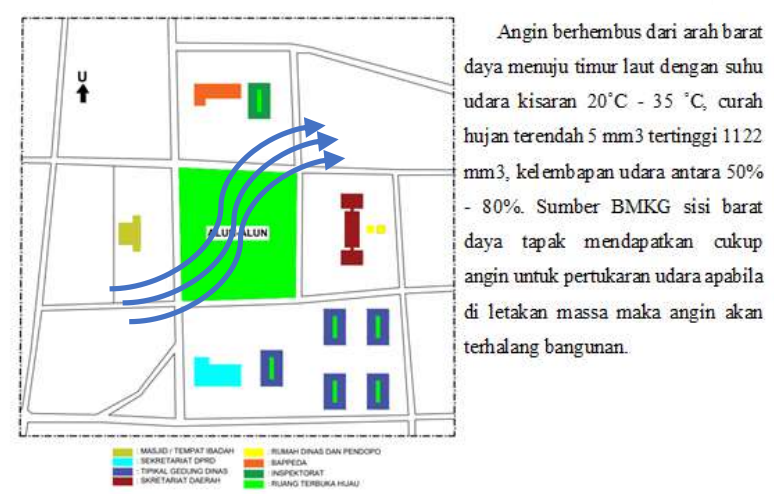

Memaksimalkan penghawaan alami dan di minimalisir mengganggu kenyamanan dalam bangunan. Menggunakan cross ventilation dan menggunakan stack ventilation

- Membentuk massa yang dapat mengatur aliran angin dan air hujan.

- Menggunakan sun shading bertujuan agar mengatur angin yang masuk dalam ruang dan mengurangi tampias.

- Penggunaan vegetasi untuk menyegarkan udara di sekitar maupun dalam ruang

- Penggunaan vegetasi untuk mengurangi polusi udara dari asap kendaraan dan mengurangi kelembaban.

- Penataan massa di buat sesuai dengan Analisa iklim yang sudah di dapatkan untuk merespon iklim sekitar.

- Menata public space untuk mendekatkan masyarakat dengan pemerintah.

Gambar 7 Konsep terhadap analisa angin dan hujan

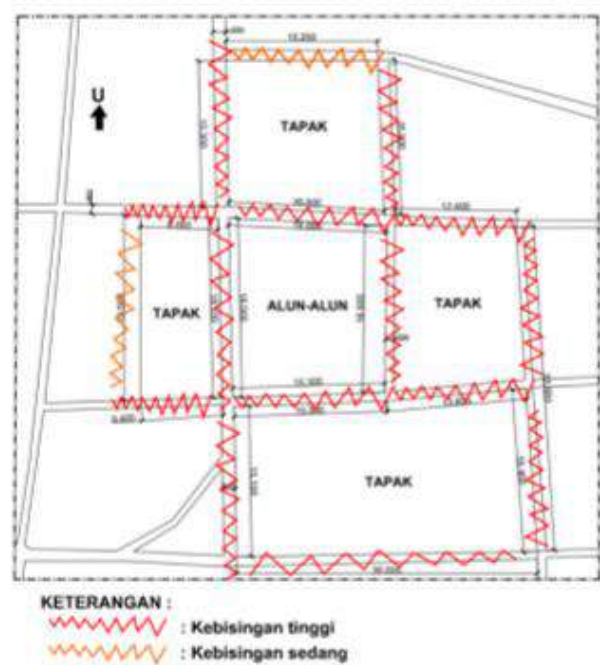

Gambar 8 Konsep terhadap analisa angin dan hujan

Untuk mengurangi kebisingan dapat dilakukan dengan penataan pemberian vegetasi berupa pepohonan di sekeliling site, pada indoor dan adanya dinding pembatas (pagar) agar tingkat kebisingan dapat di netralisir.

Cara mengatasi Kebisingan di sekitar tapak yaitu :

- Penggunaan material dengan bahan kedap suara

- Penggunaan vegetasi guna mengurangi kebisingan

- Memperluas garis sempadan bangunan (GSB)

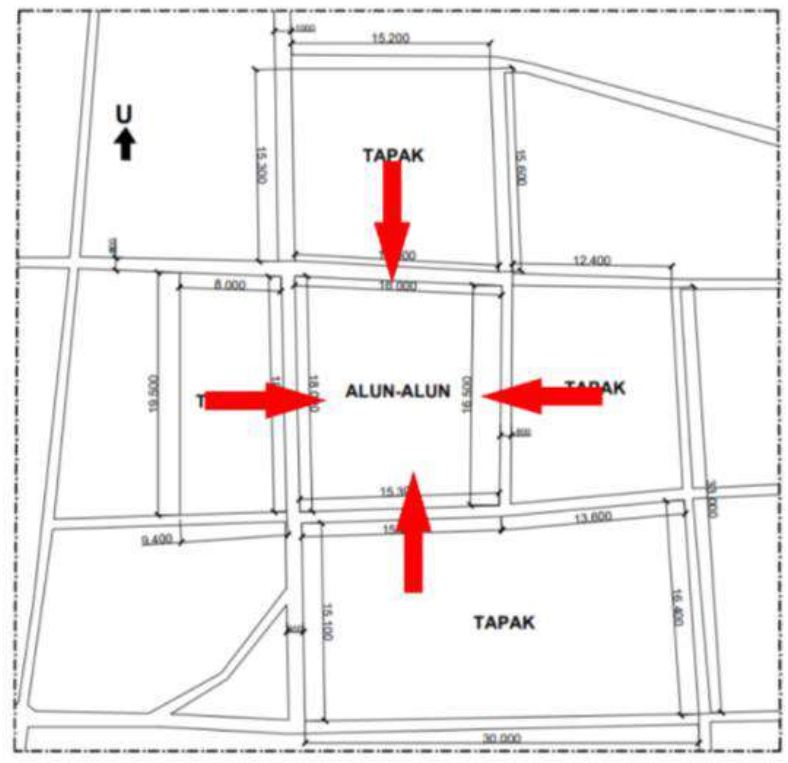

Orientasi bangunan menghadap ke alun-alun sebagai pusat dari Kawasan pusat pemerintahan yang sedang di rancang agar masyarakat berkesan lebih dekat dengan pemerintahnya

Gambar 9 Konsep Terhadap Orientasi Tapak 


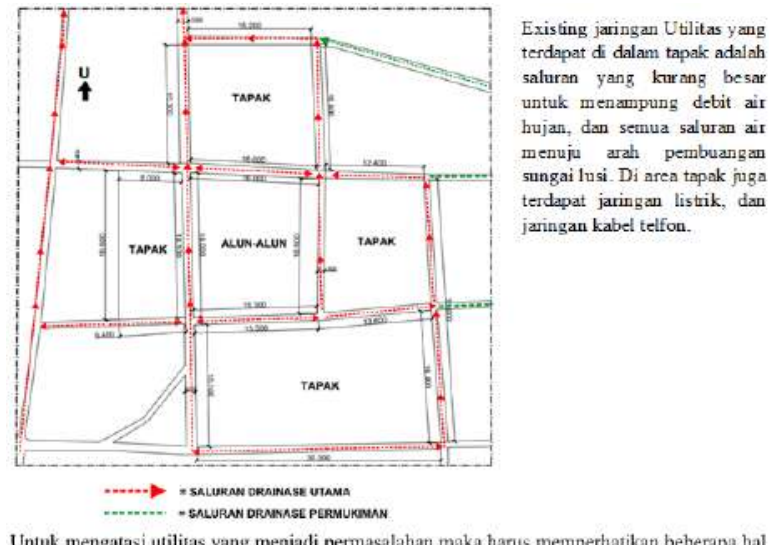

Untuk mengatasi utilitas yang menjadi permasalahan maka harus memperhatikan beberapa hal antara lain:

- Saluran drainase existing di perbaiki dan memperbesar saluran untuk menampung debit air hujan yang selama ini menjadi kendala.

- Penggunaan material perkerasan yang memiliki resapan air agar tidak menggenang di sekitar bangunan.

- Penataan Kabel yang tidak tertata.

Gambar 10 Konsep Terhadap Utilitas

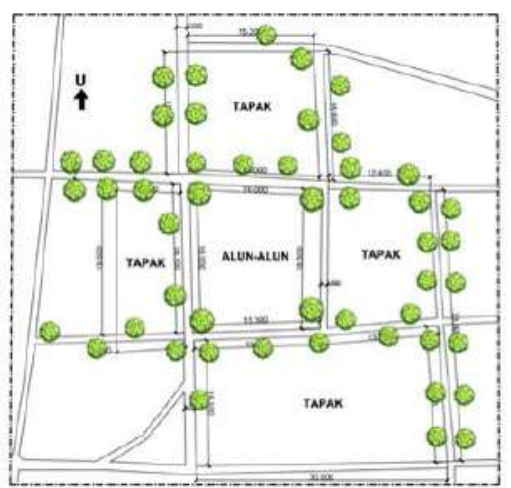

Gambar 11 Konsep Terhadap Vegetasi

Respon:

a. Konsep landscape mengambil plotting menurut iklim tropis yaitu meneduhi area tertentu agar ketika fungsi suatu bangunan dapat maksimal dengan adanya peneduh dan meningkatkan fungsi lingkungan.

b. Pohon dengan tajuk lebar diletakan pada halaman yang cukup luas agar tidak banyak pohon yang ditanam.

c. Pohon dengan ukuran sedang menjadi pengarah angin terletak disepanjang sisi pathway.

d. Pohon dengan identitas lokal ditanam pada ar ea publik untuk menguatkan spirit cultural center itu sendiri.

e. Perkerasan yang digunakan dipilih bentuk mendekati batu alam yaitu jenis andesit cobble stone yang menjadi perkerasan utama yang menghubungkan antar fungsi bangunan namun tidak semua lahan menggunakan perkerasan hanya jal an untuk mengarahkan dari bangunan 1 ke yang lain. Sedangkan jenis grass block diposisikan diarea parkir agar area resapan air tetap terjaga namun terhindar dari becek saat hujan.

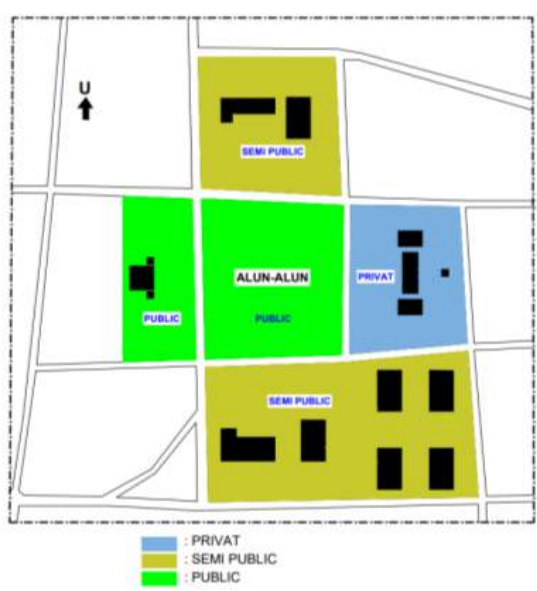

Pembagian Zoning pada tapak di bagi menjadi beberapa kelompok, berdasarkan sinar matahari yang terbit dari sebelah timur pada tapak di gunakan sebagai area privat karena cenderung tidak panas.

Pada bagian selatan dan utara merupakan area semi public karena tapak di gunakan untuk fasilitas pelayanan masyarakat

Pada bagian barat di buat untuk public yaitu sebagai tempat ibadah orang muslim (masjid)

Gambar 12 Konsep Pembagian Zonning

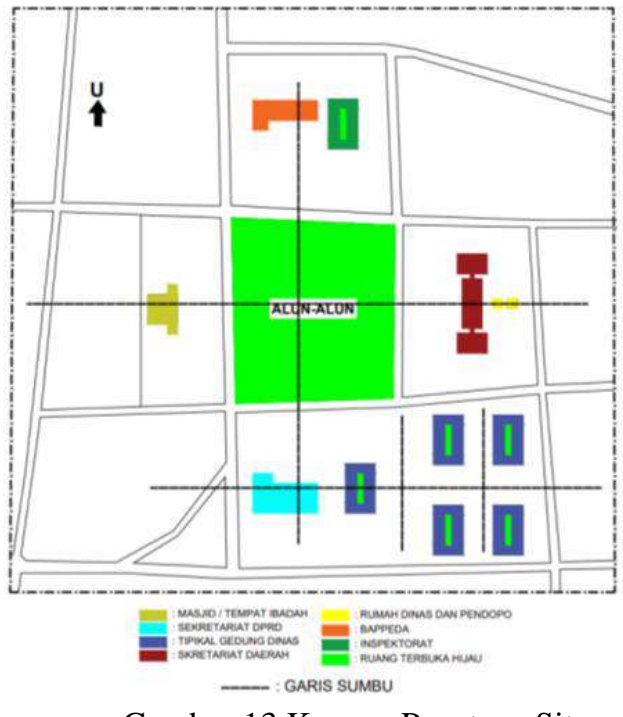

Gambar 13 Konsep Penataan Site

Keterangan :

Konsep penataan site ini menggunakan Penataan linier. Gedung sekretariat daerah di letahkan di sebelah timur menjadi satu sumbu dengan tempat ibadah bertujuan agar pemerintah yang menjabat selalu ingat kepada sang pencipta untuk tidak bertindak menjadi seorang koruptor. Satu sumbu antara Gedung secretariat daerah ini menjadi hirarki. Gedung sekretariat daerah menjadi hirarki dalam perancangan ini. 


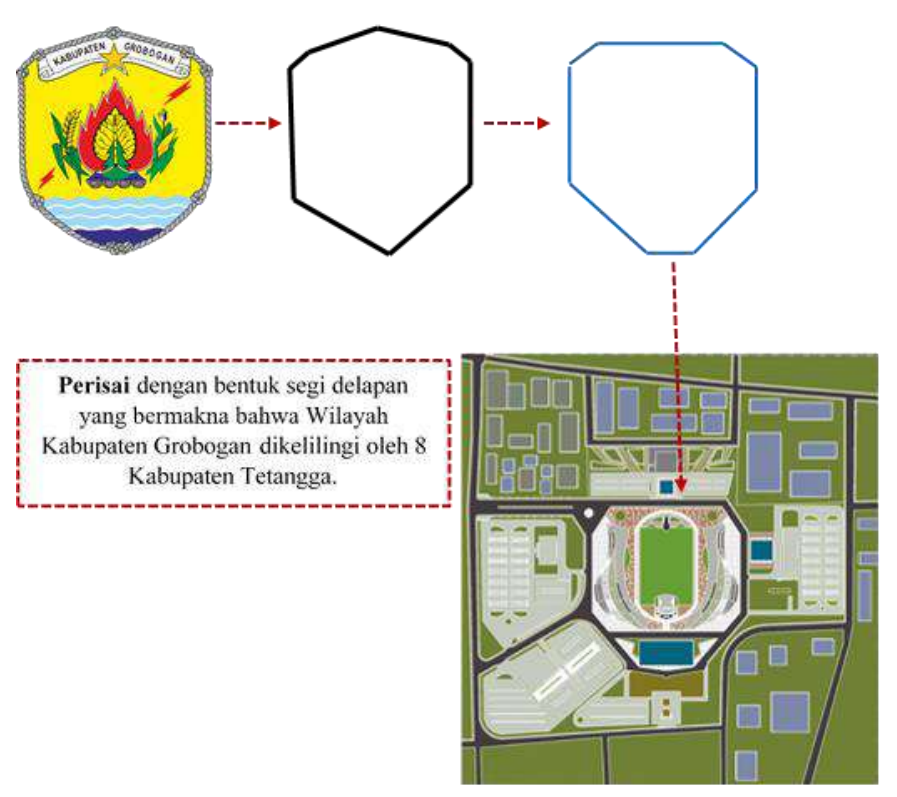

Terdapat 3 Kolam Utama Melambangkan 3 sungai utama, yaitu Sungai Tuntang, Serang dan Lusiyang yang berguna bagi rakyat Kabupaten Grobogan.
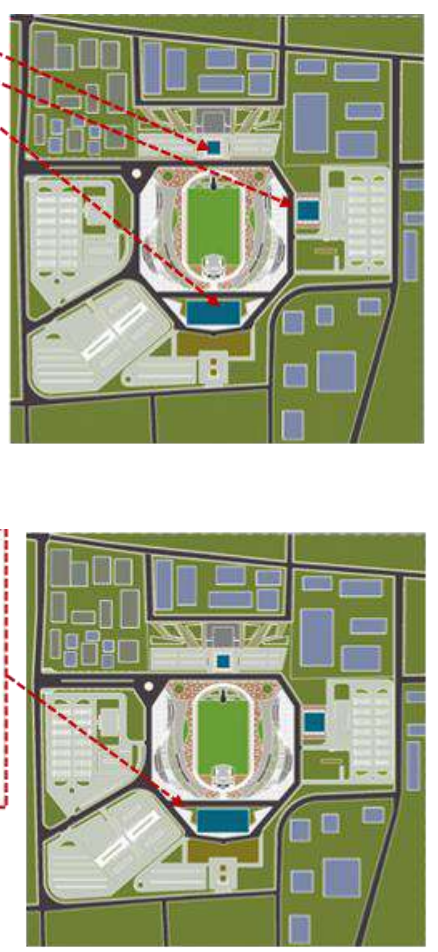

Penampang melintang belahan bambu yang dijajarkan (Klakah)

"Klakah" adalah tempat pembuatan garam darat yang khas di Kabupaten Grobogan sebagai lambang kerajinan rakyat di bidang industri kecil,
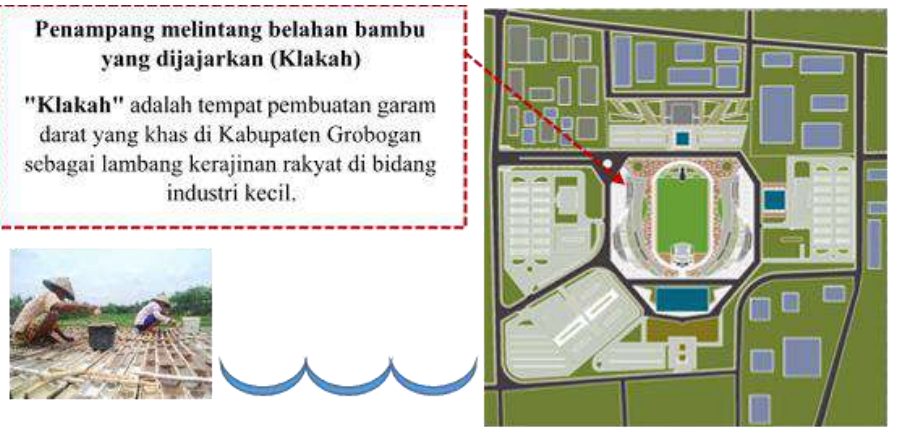

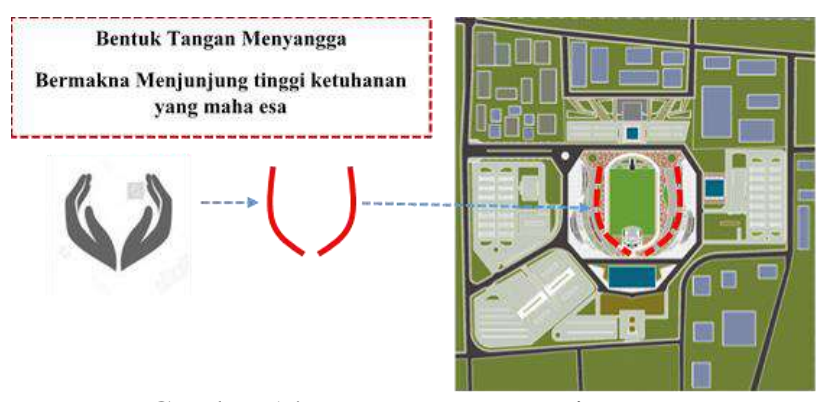

Gambar 14 Konsep Penataan site

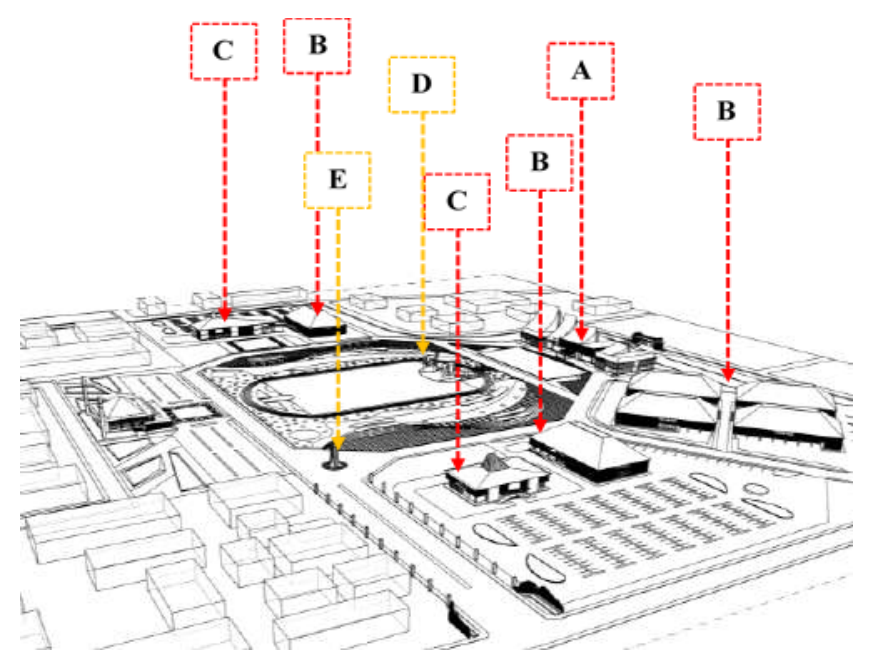

Keterangan :

A : Massa Bangunan Utama

B : Massa Bangunan Kedinasan

C : Massa Bangunan Bappeda danDPRD

D : Massa Iconik Obor

$\mathrm{E}$ : Massa Iconik Bambu Runcing

Gambar 15 Konsep Gubahan Massa

\section{A. Konsep Gedung Utama}

Bangunan Utama yaitu Gedung Sekretariat daerah kabupaten Grobogan konsep gubahan massa dengan menggunakan bentuk atap rumah joglo mempunyai filosofi atap menjulang keatas yang berarti menjunjung tinggi atas pemerintahan yang ada di kabupaten grobogan.

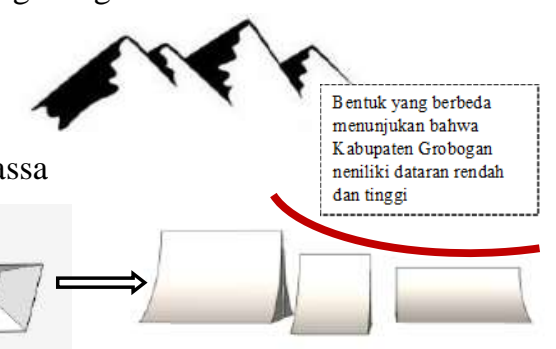

Gambar 16 Gubahan Massa Gedung Sekretariat Daerah 
mempertahankan, membela dan mengisi kemerdekaan.

\section{B. Konsep Gedung Kedinasan}

Konsep Bangunan kedinasan dengan menggunakan bentuk atap rumah joglo yang di transformasi dengan memberikan lubang pada tengah atap. Bertujuan untuk penghawaan dan sirkulasi angin. Dan pada bagian tengah tersebut digunakan sebagai open space.

Transformasi Massa

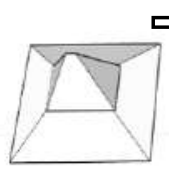

1

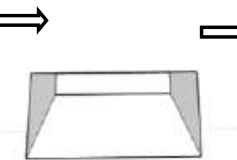

2

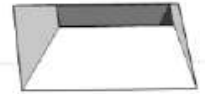

3
Gambar 17 Gubahan Massa Gedung Kedinasan

\section{Konsep Gedung Bappeda dan DPRD}

Konsep Atap bangunan Bappeda dan DPRD dengan menggunakan bentuk atap rumah joglo yang di transformasi dengan memberikan material sirap kaca yang berfungsi untuk memaksimalkan cahaya matahari dan penghawaan alami masuk secara maksimal.

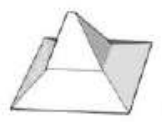

1

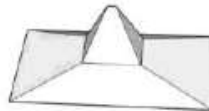

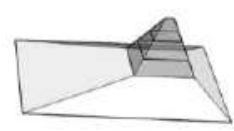

3
Gambar 18 Gubahan Massa Gedung Bappeda dan DPRD

\section{Konsep Iconic Obor}

Konsep Melambangkan sumber api alam di Kabupaten Grobogan (Mrapen), sebagai simbol kehidupan dengan semangat yang menyala-nyala dan tidak pernah padam.

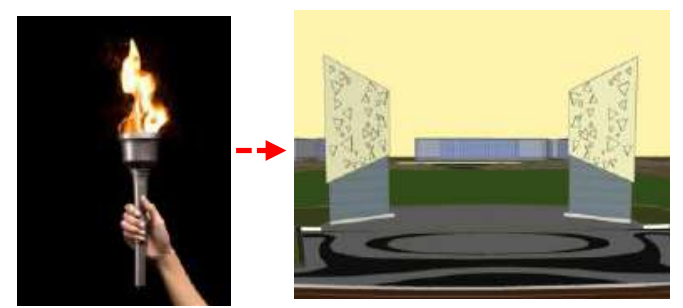

Gambar 19 Gubahan Massa Iconic Obor

E. Konsep Iconic Bambu runcing

Konsep Melambangkan semangat seluruh rakyat dalam memperjuangkan,

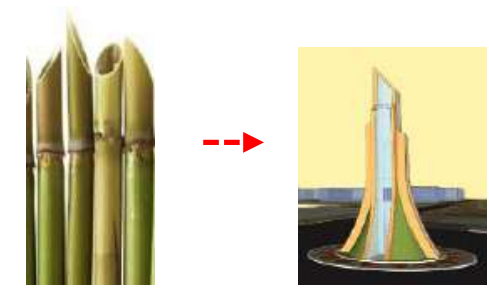

Gambar 20 Gubahan Massa Iconic Bambu Runcing

\section{KESIMPULAN}

Dalam Perencanaan dan Perancangan Pusat Pemerintahan Baru Kabupaten Grobogan di Kecamatan Purwodadi menggunakan konsep pendekatan Arsitektur Neo vernakular. Dimana menggunakan transformasi penekanan bentuk atap rumah joglo yang identik dengan rumah adat istiadat jawa tengah yang bertujuan untuk melestarikan rumah adat yang ada di jawa tengah dan di trasformasi kedalam bentuk yang modern, serta mengambil dari letak dari daerah itu sendiri dari segi kondisi geografis sampai filosofi lainya sebagai pendukung dalam mendesain

Perencanaan dan perancangan Pusat Pemerintahan ini diharapkan menjadikan sebuah kawasan dari pusat pemerintahan daerah yang baik dan memadai agar mendukung kinerja dan kualitas pemerintahan, serta memberikan pelayanan yang terbaik untuk masyarakat, memberikan publik space yang memadai yang untuk mendekatkan masyarakat dengan pemerintah karena pemerintah yang baik adalah pemerintah yang dekat dengan rakyatnya. Dan ini menjadi program daerah untuk menjadikan program yang harus di persiapkan masa mendatang.

Konsep Analisa tapak bangunan berorientasi menghadap ke alun-alun sebagai pusat berkumpulnya masyarakat, menggunakan system linier dalam merancang tapak dengan menjadikan satu sumbu antara Gedung sekretariat daerah dengan tempat ibadah bertujuan supaya pemimpin yang sedang menjabat selalu ingat dengan sang pencipta agar tidak melakukan tindakan koruptor.

Memperluas publik space yang bertujuan untuk mendekatkan masyarakat kepada pemerintah karena pemerintah yang baik adalah pemerintah yang dekat dengan rakyatnya. 
Khususnya di alun-alun dijadikan sebuah public spase yang aktif untuk aktivitas masyarakat berinteraksi dan berkomukasi dengan pemerintahnya.

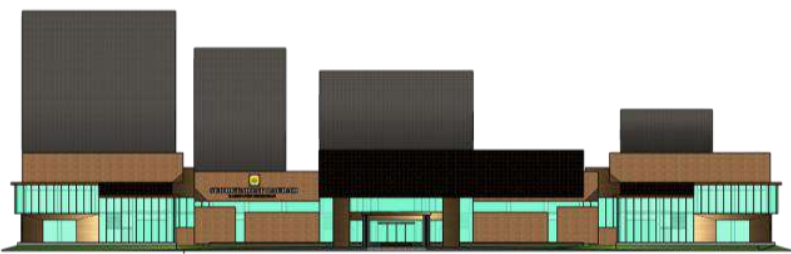

Tampak Depan

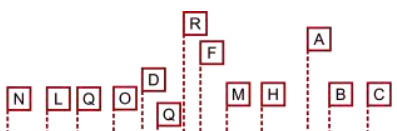

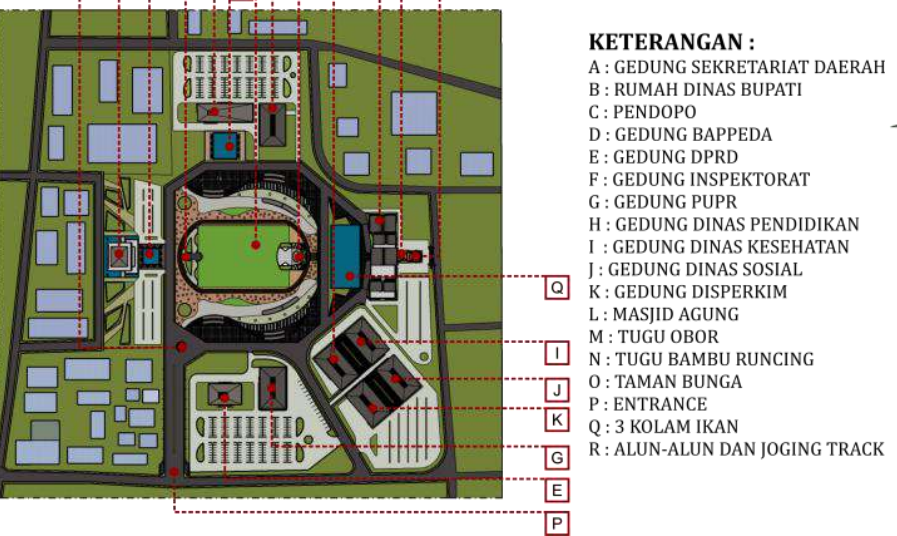

Gambar 21 Siteplan

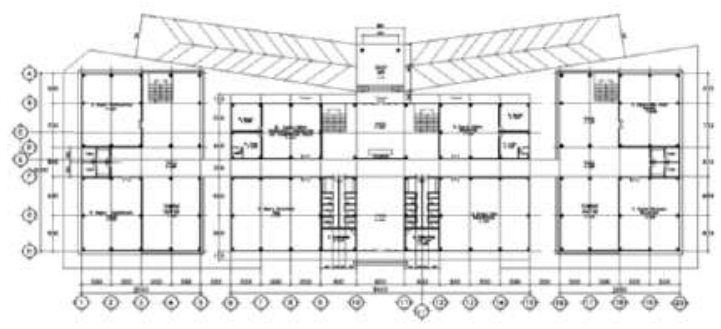

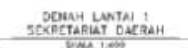

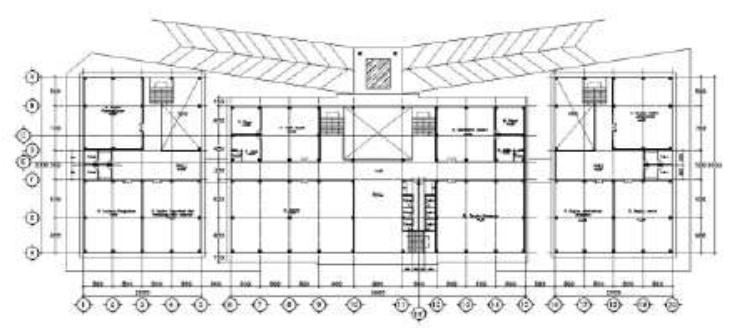

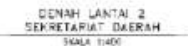

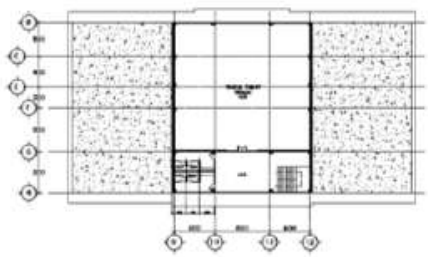

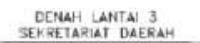

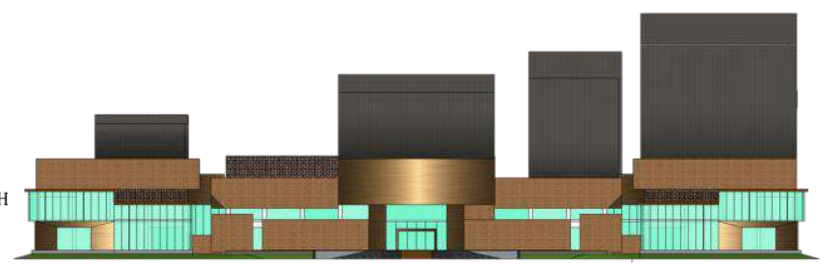

Tampak Belakang

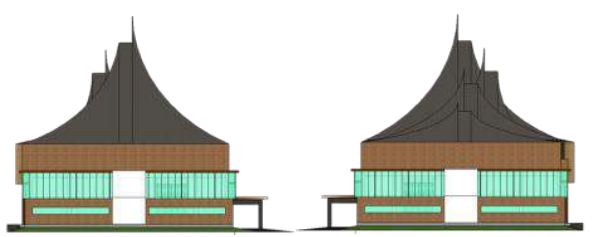

Tampak Samping

Gambar 22 Gedung Sekretariat Daerah
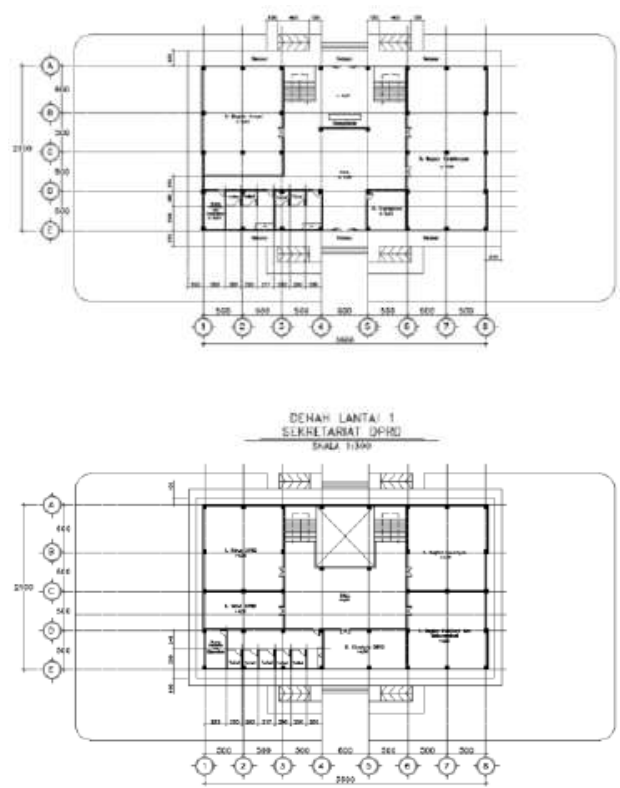

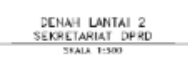

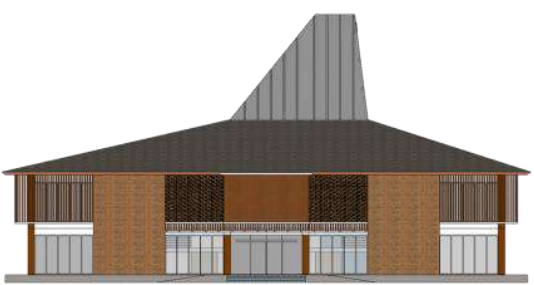

Tampak Depan 


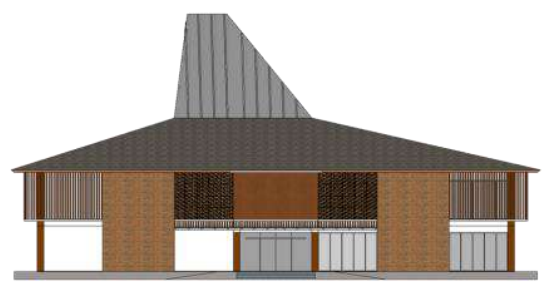

Tampak Belakang

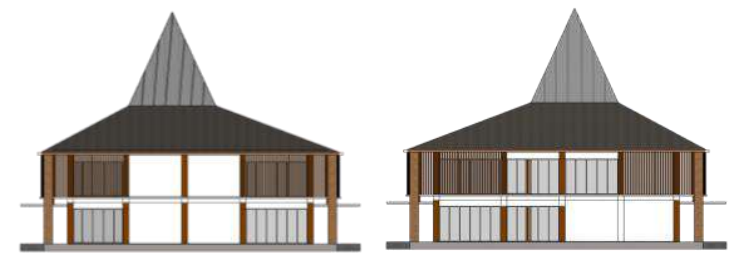

Tampak Samping

Gambar 24 Gedung Sekretariat DPRD

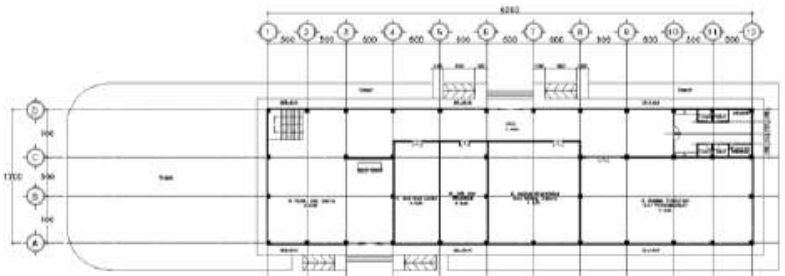

Lantai 1

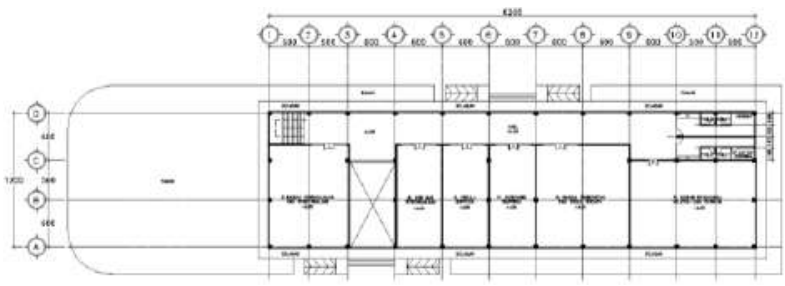

Lantai 2

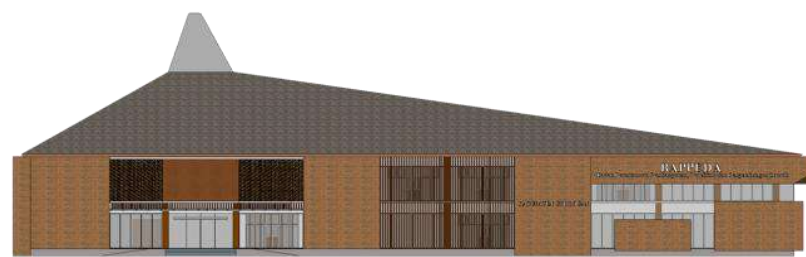

Tampak Depan

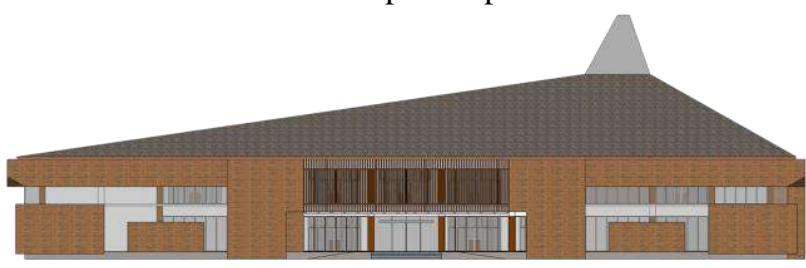

Tampak Belakang
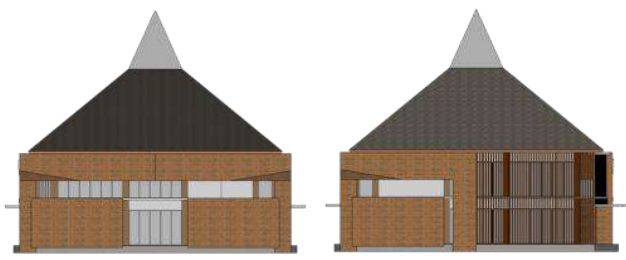

Tampak Samping

Gambar 25 Gedung BAPPEDA

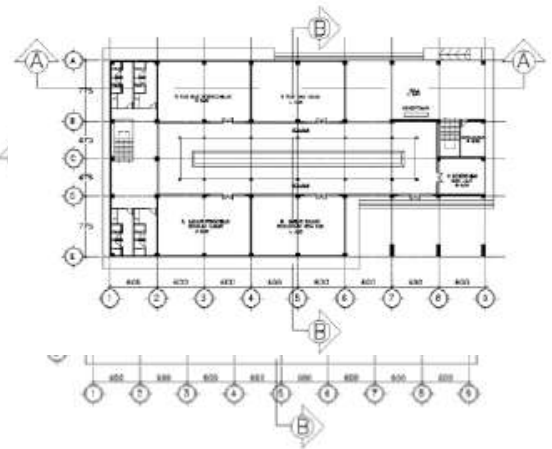

Lantai 2

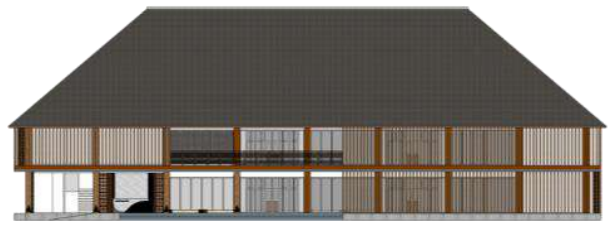

Tampak Depan

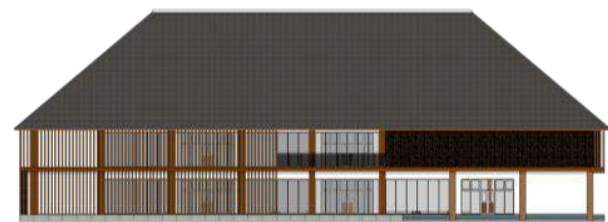

Tampak Belakang

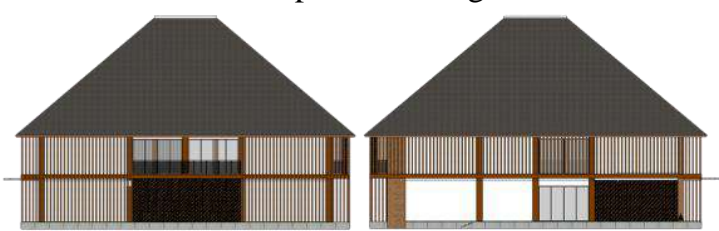

Tampak Samping

Gambar 26 Prototype Gedung Kedinasan
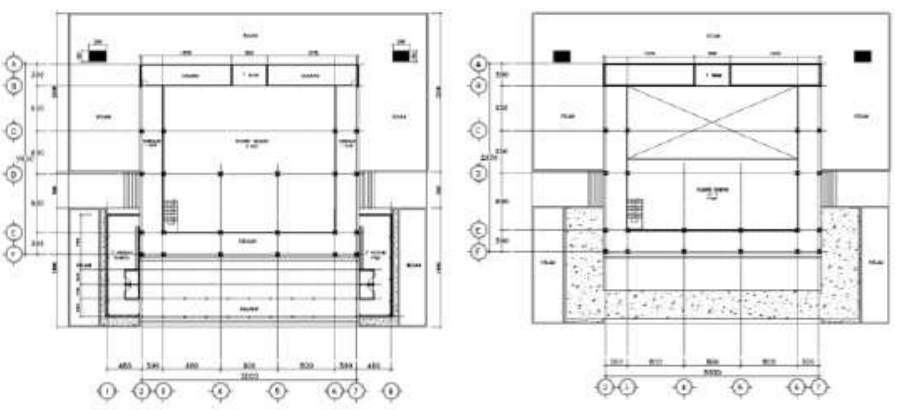

Lantai 1 \& 2 Masjid 


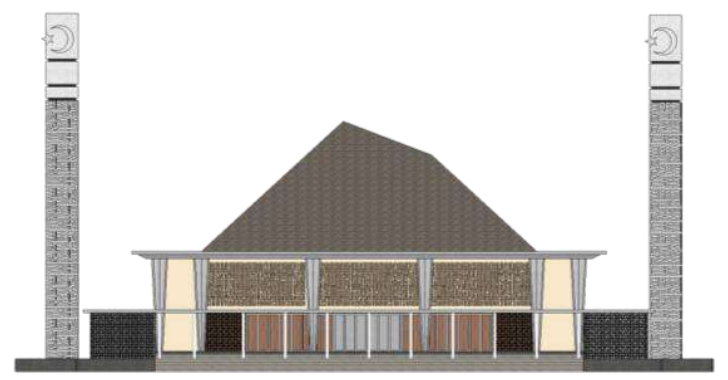

Tampak Depan

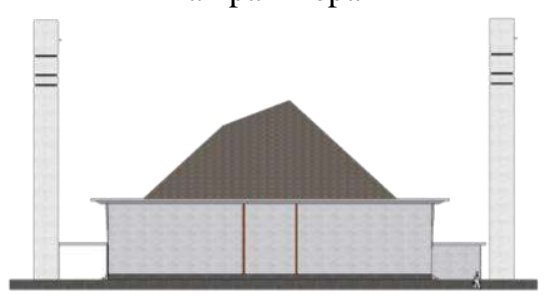

Tampak Belakang

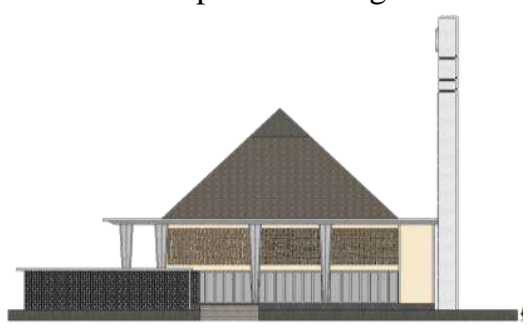

Tampak Samping Kanan

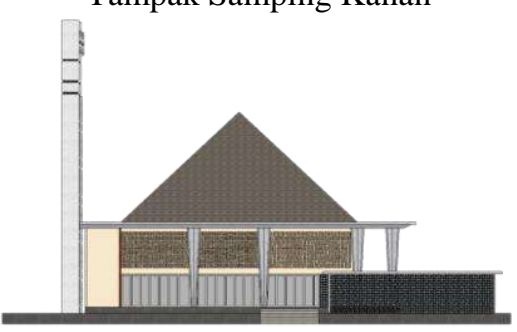

Tampak Samping Kiri

Gambar 27 Masjid

\section{D Perspektif}

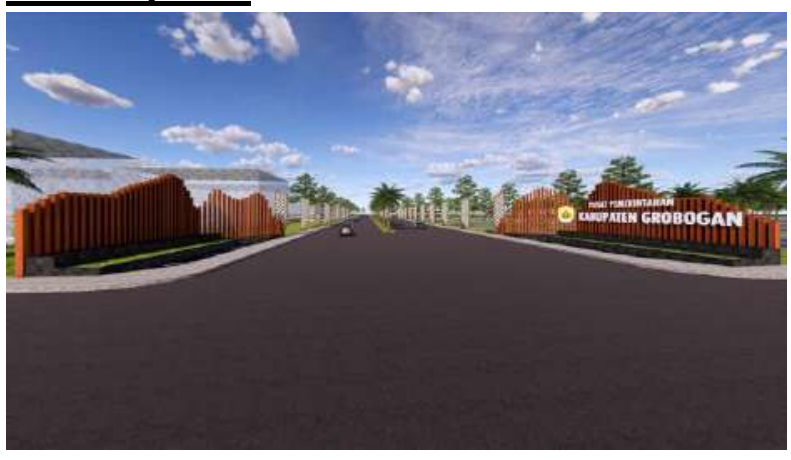

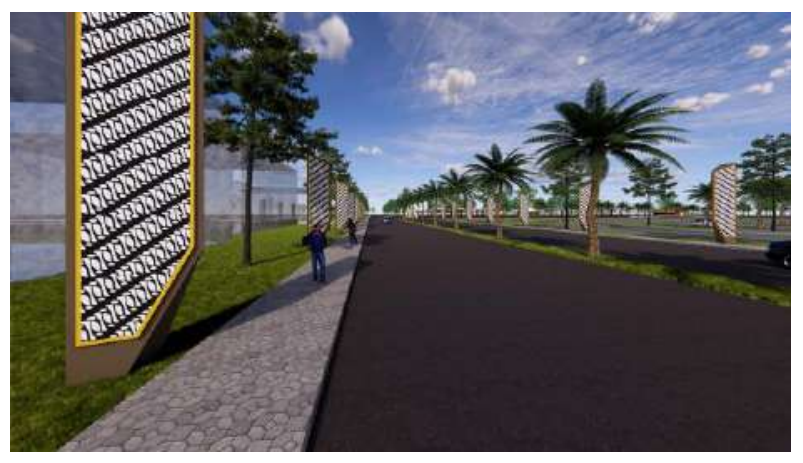

Gambar 28 Enternce

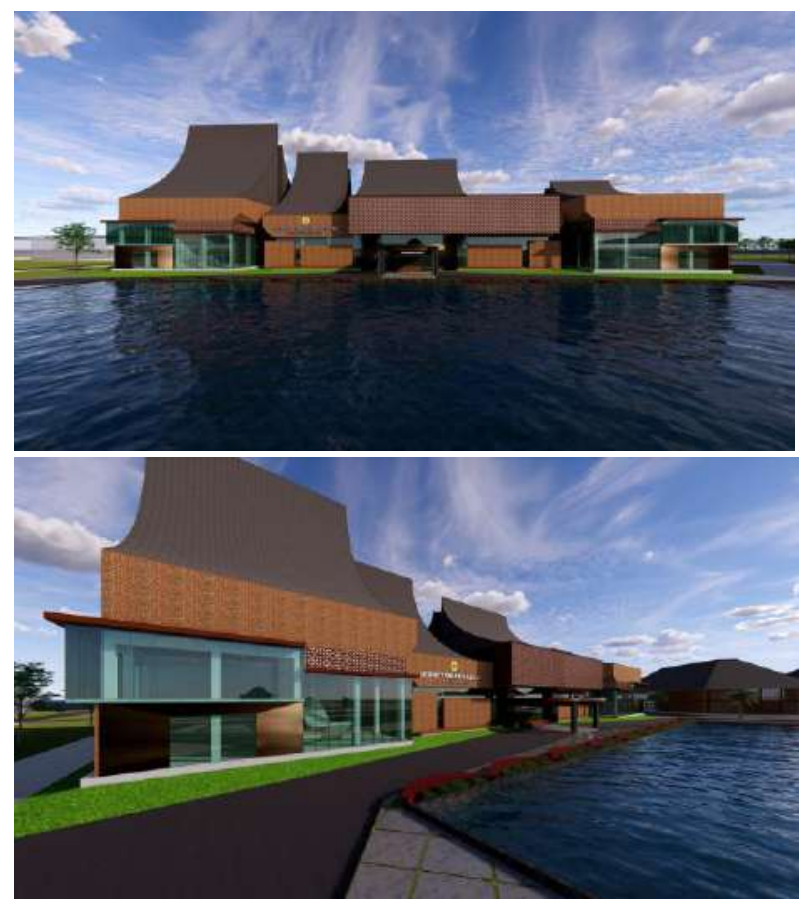

Gambar 29 Gedung Sekretariat Daerah

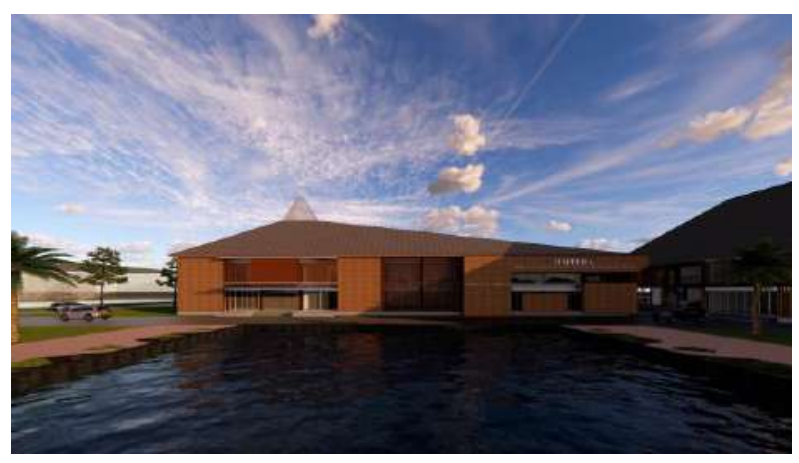

Gambar 30 Gedung BAPPEDA 


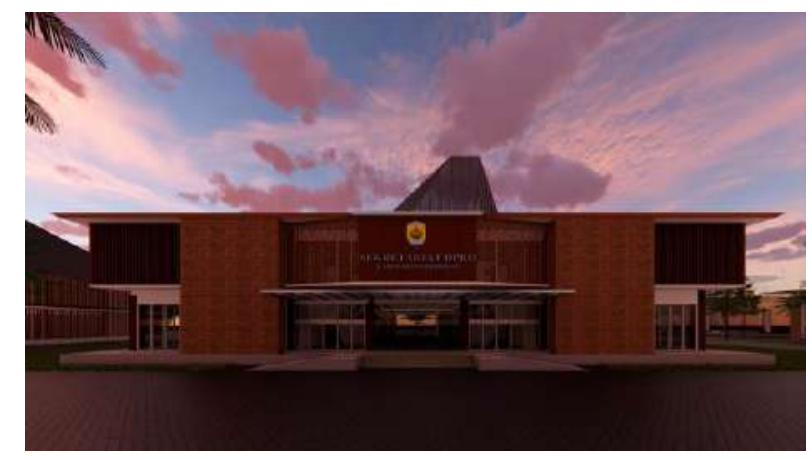

Gambar 31 Gedung DPRD

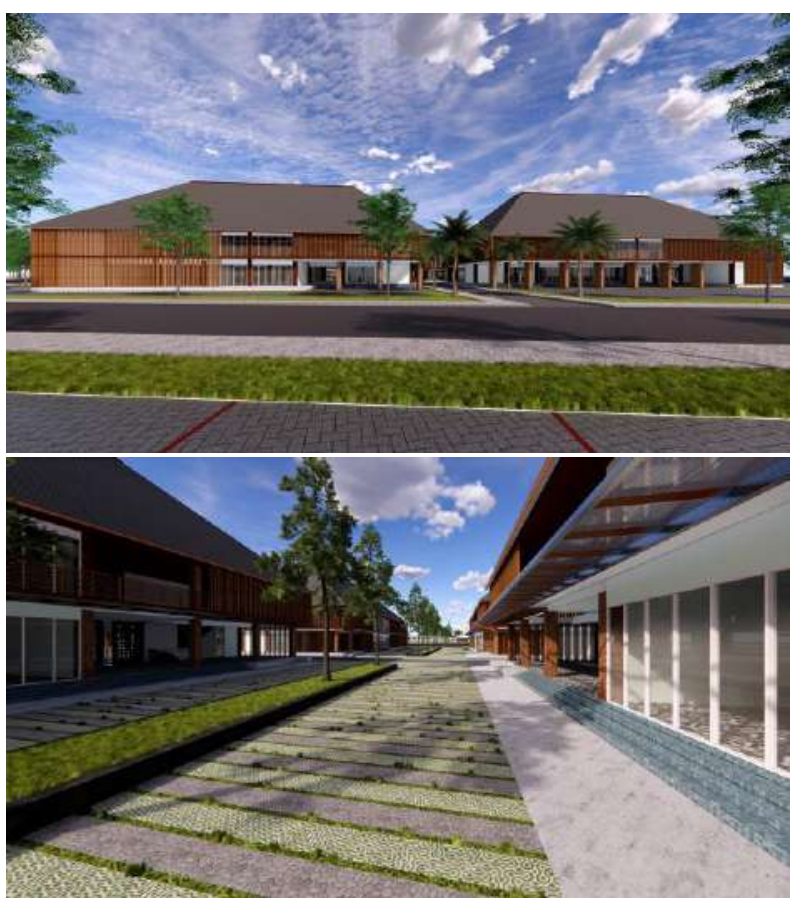

Gambar 32 Gedung Kedinasan

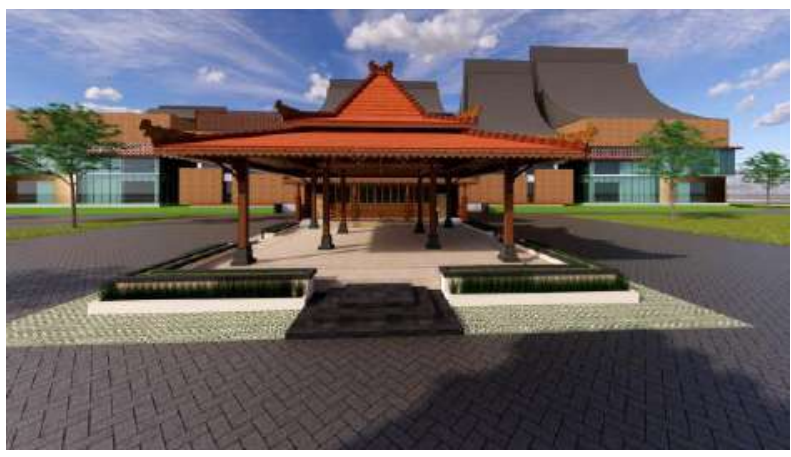

Gambar 33 Pendopo

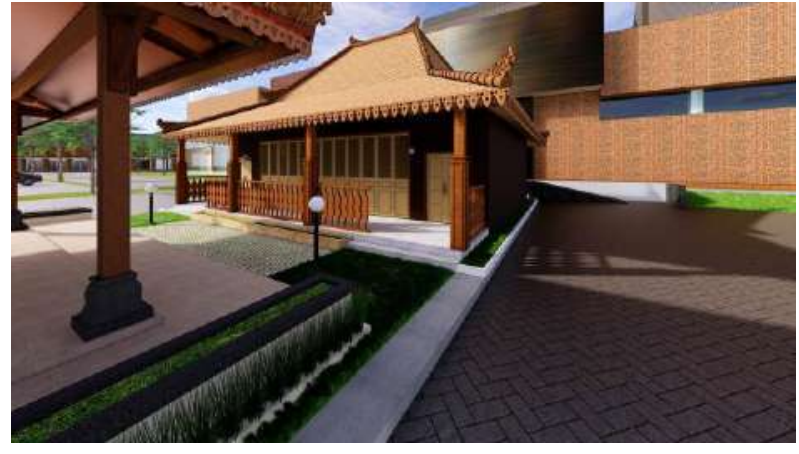

Gambar 34 Rumah Dinas
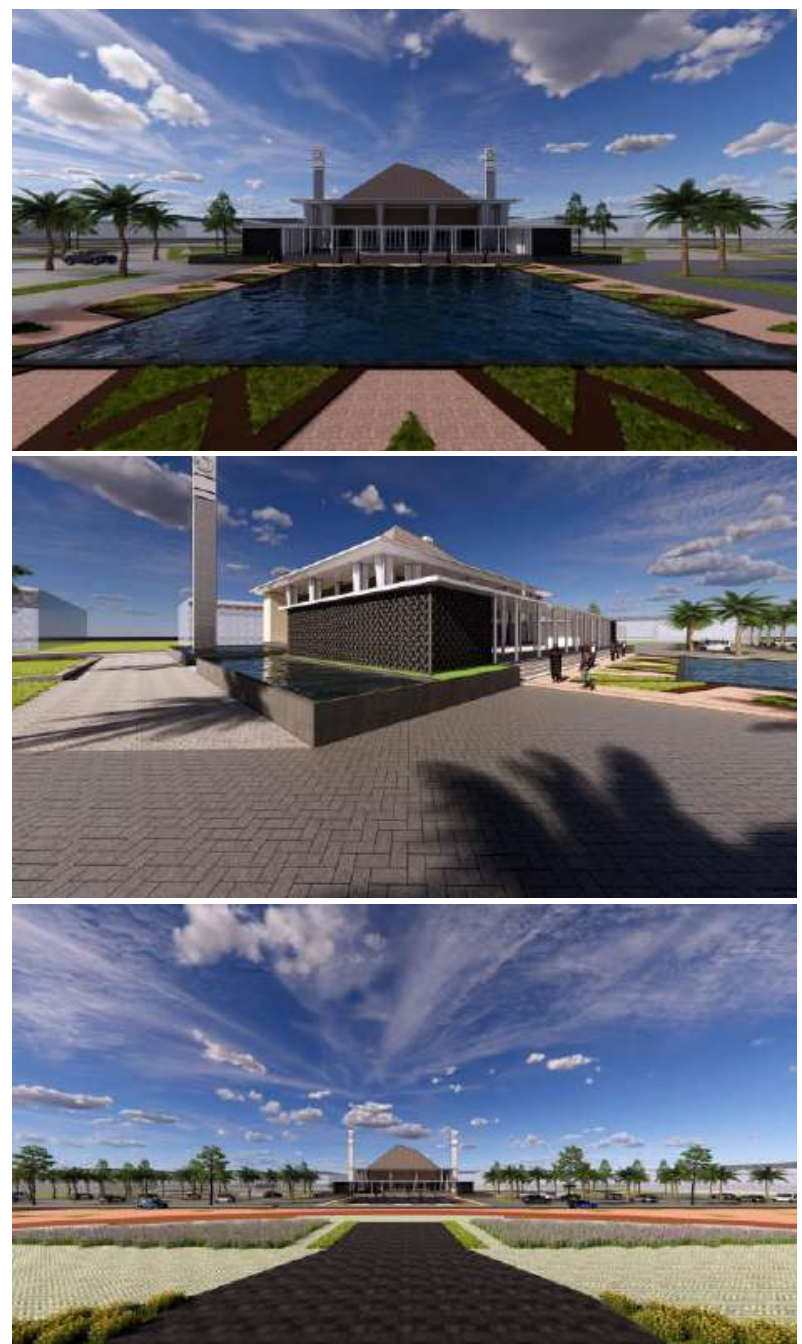

Gambar 35 Masjid 


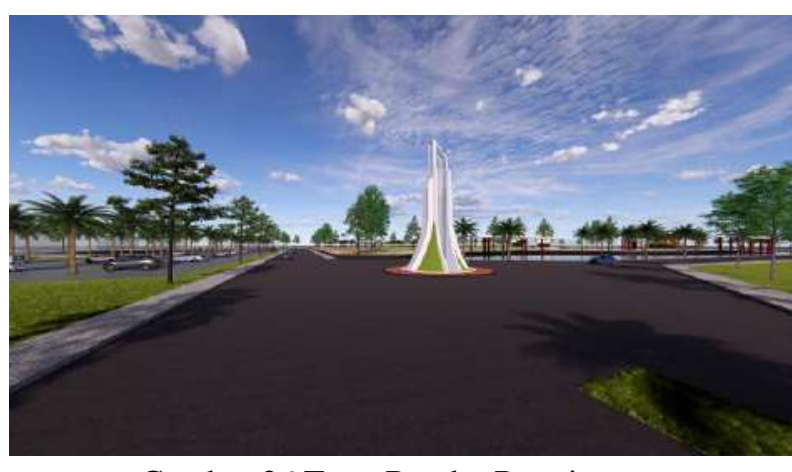

Gambar 36 Tugu Bambu Runcing

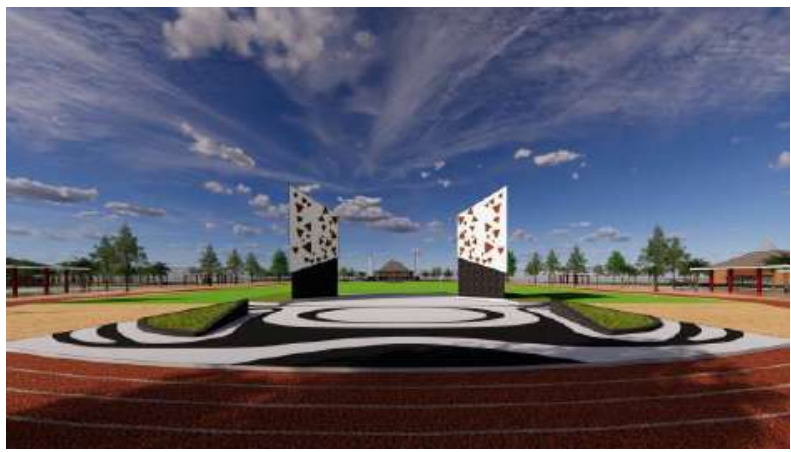

Gambar 37 Tugu Obor

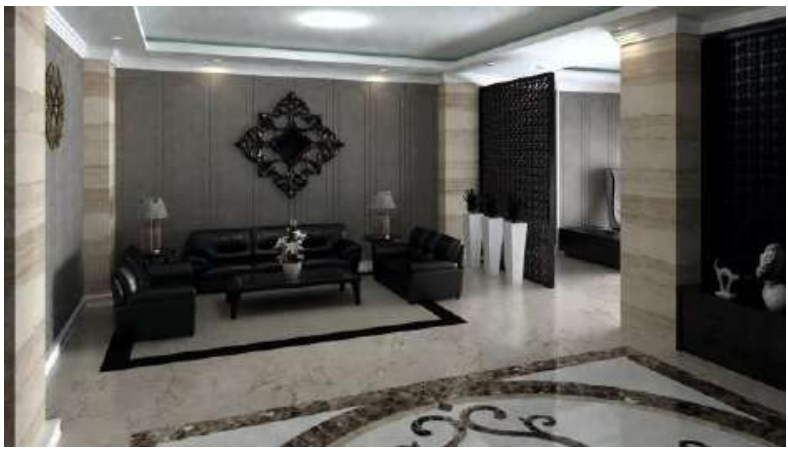

Gambar 38 Interior Ruang Tamu Bupati

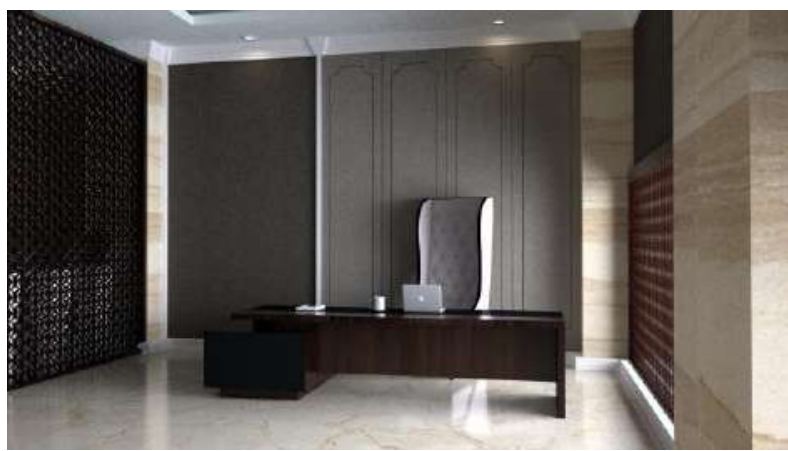

Gambar 39 Interior Ruang Kerja Bupati

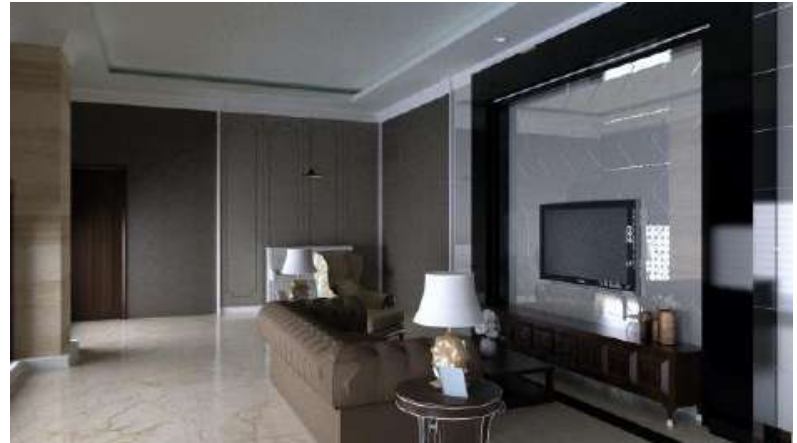

Gambar 40 Interior Ruang Santai/Tamu Khusus Bupati

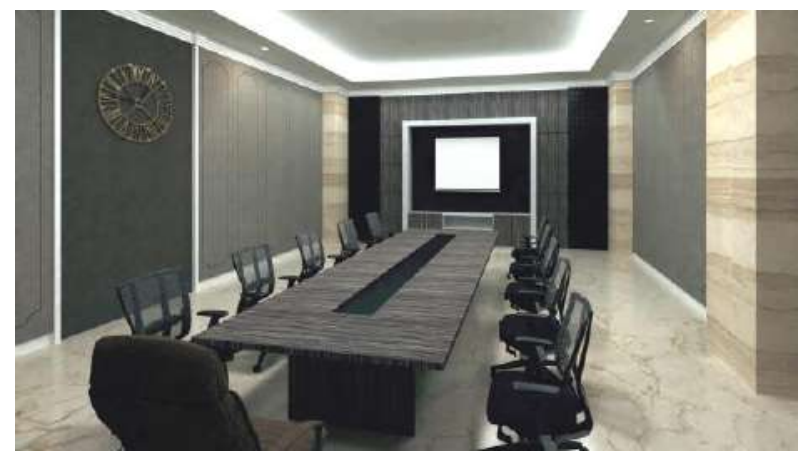

Gambar 41 Interior Ruang Rapat Bupati

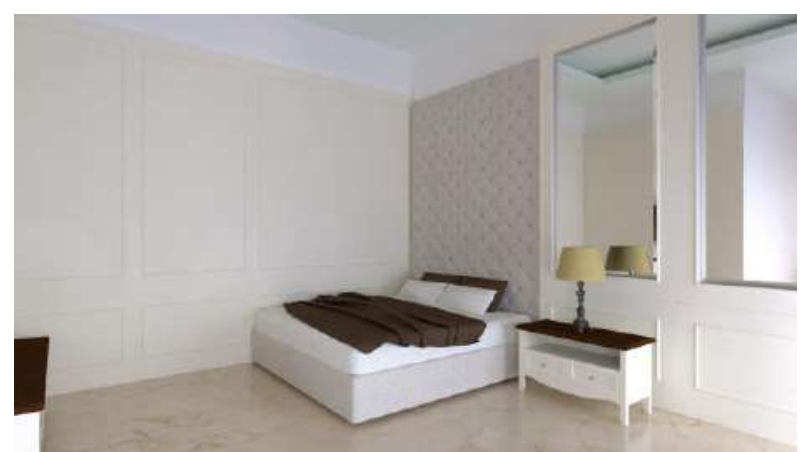

Gambar 42 Interior Ruang Istirahat Bupati

\section{DAFTAR PUSTAKA}

Inu Kencana Syafiie (2011), Pengantar ilmu pemerintahan, Jakarta, Refika Aditama.

Ir. H. Sidik Hananto, MT (2010), Fisika Bangunan. Bandung: Universitas Pendidikan Indonesia.

Jencks, Charles, author (1991)"The Language of Post-Modern Architecture". New York: Rizzoli.

Peraturan Menteri Dalam Negeri Nomor 7 Tahun 2006 Tentang Standarisasi Sarana Dan Prasarana Kerja Pemerintahan Daerah.

Ridwan HR, (2002), Hukum Administrasi Negara, Yograkarta, UII Press. 
https://www.arsitur.com/2017/11/pengertianarsitektur-neo-vernakular.html diakses 5 september 2020

https://eivellyn.wordpress.com/2014/06/11/golo ngan-kepangkatan-dan-golongan-eselonpada-pns/ diakses 17 Oktober 2020

https://www.grobogan.go.id/profil/lambangdaerah/makna-lambang-daerah

https://www.jogloabang.com/gaya/pp-18-2016perangkat-daerah diakses 5 september 2020 https://peraturan.bpk.go.id/Home/Details/12644 9/permendagri-no-7-tahun-2006 diakses 17 Oktober 2020 